\title{
Patrick Goujon
}

Les jésuites aujourd'hui: Depuis leur rétablissement (1814). Paris: Facultés jésuites, 2015. Pp. 121. Pb, €10.

This is an informative and thoughtful book, a collection of essays, as the title and subtitle say, on Jesuits today, since the restoration in 1814. The occasion was a meeting held in 2014 at the Centre Sèvres, the site of the "Jesuit Faculties" in Paris. The seven presentations begin from the suppression and restoration themselves, to the paradoxes of the history of the Jesuits in France in the nineteenth century, the social, spiritual, and intellectual engagement of the French Jesuits in the twentieth century, apostolic issues of Jesuit education, the missionary challenges of the Jesuits in India today, and Teilhard de Chardin in China.

In the essay on suppression and restoration, Patrick Goujon, S.J., professor of theology at Centre Sèvres, not only tells the story of the worldwide suppression and restoration, he also raises important questions: How did an "esprit de corps" survive among so many of the former Jesuits when they were without an exterior corporate structure or specific apostolates, in the midst of the upheavals of the French Revolution and the Napoleonic empire? What happened in the places that made possible the restoration? What patient background projects were indeed going on so that the restoration could eventually take place?

In the course of dealing with the paradoxes of the Jesuits in France in the nineteenth century, Claude Langlois, emeritus professor of history at the École Pratique des Hautes Études, treats three major topics: the great difficulty in even speaking of the Society of Jesus in the nineteenth century; the difficulty in the search for identity of the Jesuits in the nineteenth century; and the changes in the Society, quiet but decisive, in the years before wwI. In each of those sections, there are remarks on such questions as the burdens of anti-Jesuitism, the growth in membership, in schools, in apostolic works; the political world in which the Society lived and worked. Each part of the essay is illuminating, but the last one is especially so. This involved the return to the sources of the Society, the initiatives toward serious scholarship in theology, history, and biblical sources, and the popular and scholarly openings toward social concerns.

Philippe Lécrivain, S.J., emeritus professor of the history of Christianity at Centre Sèvres, presents a further understanding of the engagements, social, spiritual, and intellectual, of the French Jesuits from the 1920s to our present day. In broad strokes and with multiple specific examples, his presentation traces the social, spiritual, and intellectual engagements of the French Jesuits in the course of the past century. After the Vichy years and the calls to conscience that it provoked, came several post-war crises, such as the "case" of 
Teilhard, the Roman crackdown on the nouvelle théologie, and the priest-worker apostolate. And then finally the new hopes brought on by Vatican II and the Jesuit generalate of Pedro Arrupe. All of this is dealt with in the context of one underlying reality, how the French Jesuits were faithful to the spirit of their founder.

The paper by Michael Amaladoss, S.J., moves from Europe to Asia, and to the "missionary challenge of the Jesuits in India today." This chapter of the book contains first, a brief historical survey of Jesuit India, with some special reference to the French Jesuits who first arrived there in 1689. It then goes on to examine several major challenges such as the "option for the poor" and the dialogue with culture and with religions in the context of the current political realities of India, especially the rise of "Hindutva," Hindu nationalism.

Benoît Vermander, S.J., professor at Fudan University in Shanghai, shares his reflections on Teilhard de Chardin in China, reflections that arose out of a traveling scholarly seminar that took place in 2013 in Mongolia. Out of that seminar came a documentary film entitled "Teilhard in China," shown for the first time after this meeting at Centre Sèvres. The result is an informative but primarily a moving tribute to Teilhard and his life and work.

The final essay in this book lays out what it means to be "at the heart of the human, and at the frontiers of the world, the mission of the Jesuit yesterday and today." Such is the title of that essay by Pedro Rubens, S.J., the rector of the Catholic University of Pernambuco, Recife in Brazil and the president of the International Federation of Catholic Universities. The material is both universal in its scope and particular in its details. It is also dense in its style and rather lengthy.

The author wishes to speak of the strategic options in the mission of the Society in three distinct perspectives, the option for the universal Society, for the Latin American Jesuits in general and for the Brazilian Jesuits in particular. He takes as his particular sources development documents of the general congregations thirty-one through thirty-five on faith and justice and on dialogue with culture and cultures and with religions, and the global apostolic preferences established by General Kolvenbach and taken up again by GC 35. Toward the end of the essay, the author proposes "certain openings" for the future. First is the mission of reconciliation. Second is the reality of Jesuits working in an apostolic network where they do not occupy the center of a particular mission because by its very nature a network is polycentric. Finally the third such opening is to "think with the Church" in ways other than in the past, in the openings made possible by the new context of the pontificate of Pope Francis.

Each of these essays presupposes to some extent a background knowledge of French Catholic nineteenth-century history. The more such background, the 
better. But whatever the case, the essays present original insights and ask pertinent questions that will not only enlighten the reader but will also stimulate that reader to learn more of nineteenth-century French Jesuit history and to ask questions that turn out to be relevant not only to that place and time but also to place and time today.

John W. Padberg, S.J.

Jesuit Community at Saint Louis University

jwpadberg@gmail.com

DOI 10.1163/22141332-00403007-02 